\title{
Impacts on travel and holiday accommodation online booking in selected South-East European countries: a multivariate analysis approach
}

\author{
Ksenija Dumičić ${ }^{1}$, Berislav Žmuk ${ }^{1, *}$ and Anita Čeh Časni ${ }^{1}$ \\ ${ }^{1}$ Faculty of Economics and Business, University of Zagreb \\ Trg J. F. Kennedyja 6, 10000 Zagreb, Croatia \\ E-mail: 〈\{kdumicic, bzmuk, aceh\}@efzg.hr〉
}

\begin{abstract}
This paper investigates the impacts of economic indicators and the Internet penetration rate, as well as people's ICT skills based on the Percentage of Individuals who booked travel and holiday accommodation over the Internet as the main variable under study. Recent data on member states in the European Union (EU28) are analyzed, including data on the three official EU candidate countries: Turkey, the FYR of Macedonia and Serbia. The research focuses on the position of the above mentioned EU candidates, considered part of South East Europe (SEE) and the Western Balkans (WB). The main variable under study and four variables making a statistically significant impact on the main variable are explored. High positive correlations between pairs of the variables for 30 countries were found. Multiple linear regression modelling using the OLS estimators resulted in several acceptable models. Most hierarchical and non-hierarchical clustering methods resulted in clear grouping of the SEE countries (Turkey, the FYR of Macedonia, Serbia, Bulgaria and Romania) into the same clusters. Other more developed SEE countries in terms of the analyzed variables and utilizing specific clustering techniques joined other EU countries in different combination setups.
\end{abstract}

Key words: booking online, profile diagram, hierarchical clustering, non-hierarchical cluster analysis, tree-diagram, linear regression modelling

Received: October 10, 2014; accepted: February 27, 2015; available online: March 30, 2015

DOI: $10.17535 /$ crorr. 2015.0013

\section{Introduction}

Modern Information and Communication Technologies (ICT) impose new extensive possibilities of Internet booking which affect both tourism demand and supply, especially in countries with higher GDP per capita. The aim of this paper is to model the relationships between the dependent variable named the Percentage of Individuals, who have booked travel and holiday accommodation over the Internet, and selected variables, related to economics and ICT in the

${ }^{*}$ Corresponding author. 
EU and several SEE countries based on recent official data for relevant development indicators. The advent of the new ICT opportunities, a higher broadband penetration rate, increased computer and Internet literacy and skills, together with an increased GDP per capita might influence the new challenges and trends in online booking of travel and holiday accommodation. Therefore, it is interesting to conduct exploration using correlation, multiple regression and cluster analysis based on the available official data for the European countries. As the clustering of similar countries all over Europe is expected, so too are South-East European countries expected to be clustered into one cluster, at least a majority of them.

The Eurostat report [5] has indicated that buying or ordering goods and services for private purposes over the Internet has become very popular in the EU28, with $61 \%$ of Internet users making such purchases in 2013, with an increase of $11 \%$ since 2008. The share of e-shoppers among Internet users varies considerably among EU member states: the highest percentages were registered in the United Kingdom (85\%), Denmark (81\%) and Germany (80\%), whereas the lowest were in Romania (15\%), Bulgaria (22\%), Estonia (28\%) and Italy (32\%). The fastest growth between 2008 and 2013, some $20 \%$ or more, was recorded in Belgium, Lithuania, Croatia, Slovakia and Malta.

The aim of this paper is to study the influence of four selected economic, social, and information and communication technologies (ICT) development indicators on booking travel and holiday accommodation online. The analysis includes European Union countries, EU28, and those South-East European countries (SEECs) that offer official data for the variables of interest, i.e. the FYR of Macedonia, Serbia and Turkey. These three mentioned SEE countries are official EU candidate countries. Given that the EU28 already includes six SEE countries: Bulgaria, Cyprus, Greece, Romania, Slovenia, and the youngest EU member -Croatia, the SEE region is represented in this research by nine countries (out of a total of 13), six of which are EU members, and three being official EU candidate countries. Due to lack of data, the following SEE countries were omitted: Albania, Bosnia and Herzegovina, Kosovo and Montenegro. Three of the analyzed countries are considered Western Balkans countries (WBC): the FYRs of Macedonia and Serbia, including Croatia, see [13]. Once again, the countries Albania, Bosnia and Herzegovina, Kosovo and Montenegro were omitted even though they are all WBCs.

According to the first research hypothesis, the percentage of individuals who booked travel and holiday accommodation over the Internet in the last 12 months in the selected European countries is expected to be positively correlated with each of the four regressors: the gross domestic product (GDP) per capita, public expenditure on education as a percentage of GDP, the Internet penetration rate, and an individual's level of Internet skills. This claim is tested using correlation and regression analysis. In respecting all the analyzed variables, it was presumed that clusters of countries might include the SEE 
countries. This assumption appeared to be a second research hypothesis, which was tested using clustering methods.

\section{Literature review}

The Internet has proved to be an integral part of the habits of millions of users [2]. Moreover, according to the above research, an effective online communication strategy is the key factor for achieving a competitive advantage on the market for satisfying actual and potential tourist information needs. Considerable increases in the volume of available tourist information have resulted from rapid technological changes, globalization and competition, meaning that both consumers and tourist destinations face complex choices [9]. Without having experience of an actual destination, tourists find if difficult to form a clear image of the destination. This is where the multimedia interactive nature of the $W e b$ comes into play opening up a whole new dimension to destination marketing [9]. Moreover, mass tourism destinations are usually subject to a substantial degree of control by tour operators, but the Internet provides an alternative distribution channel when used as a marketing tool [17]. Grønflaten [10] considers disintermediation from an information search perspective and explores the choice between two information sources: travel agents vs. service providers using websites, and the choice between two information channels (face to face vs. the Internet). Alvarez and Asugman [1] explore a segmentation design and differentiate tourists according to their perceptions of online and offline information sources when choosing their vacations. Scharlr et al. [14] have formed a comprehensive $W e b$ mining endeavor and a supplier survey to explore the effectiveness of tourism websites. They have discovered that important dimensions of automated measurement include ease of navigation, interactive elements such as reservation and booking features, volume of textual and graphical information, number of available languages and the textual diversity of documents. Accordingly, crucial elements for the success of a hotel website are its precise textual information and interactive features, measured in terms of tourist awareness, electronic inquiries, and online bookings. The article also discusses differences between four European destinations and the implications of benchmarks for website management. According to Bonn et al. [3], tourists who find destinations online spend more money at the destination of their choice than those who use other means of finding information on vacancies. Hanson [12] identified several factors indicating a positive correlation with tourist intentions to purchase vacations online. Škuflić and Štoković [15] have introduced the variable "Internet", as the percentage of online reservations and bookings indicating a change in consumer behavior. According to Dixit et al. [4], the scope of the Internet is increasing day by day. In particular, tourism products are yet to realize their complete potential. Nonetheless, the Internet has provided significant benefit to tourism 
organizations in terms of conversion costs and customer retention. Keeping this in mind, online tourism is set to reengineer most of the processes supporting travel and tours in their entirety. The results of the 2012 Flash Eurobarometer survey "Attitudes of Europeans towards Tourism" [5] has proven that Internet booking users in European countries have specific socio-demographics characteristics.

\section{Data exploration}

The main variable is the Percentage of Individuals who have booked travel and holiday accommodation over the Internet in the last 12 months $\left(\mathrm{Y}_{\text {IntBook }}\right)$ with data covering 2013, with the exception of the FYR of Macedonia for which the estimate for 2013 is based on the last available source from 2012, and that of Serbia for which the estimate is based on the year 2009. The explanatory variables are: the Gross Domestic Product per capita in Purchasing Power Standards (GDP per capita in PPS), Index, EU28=100, 2013 ( $\mathrm{X}_{\mathrm{GDPpc}}$ ); Public Expenditure on Education, given as the percentage of GDP, with data from 2010 taken as the estimates for 2013 with the exceptions of Denmark (estimate based on 2009), the FYR of Macedonia (estimate based on 2002), Greece (estimate based on 2005), Luxembourg (estimate based on 2001), Romania (estimate based on 2009), and Turkey (estimate based on 2006) ( $\mathrm{X}_{\text {ExpEduc }}$ ); the Internet Penetration Rate given as the Percentage of Individuals using the Internet with all the data for 2013 ( $\left.\mathrm{X}_{\text {IntUse }}\right)$; and the Individuals' Level of Internet Skills as the percentage of the total number of individuals aged 16 to 74 who have carried out 1 or 2 of the 6 Internet-related activities mostly given for 2013, with the exception of the FYR of Macedonia (estimate based on 2010), and Serbia (estimate based on 2007) ( $\left.\mathrm{X}_{\text {IntSkill }}\right)$. For the purpose of the analysis, official Eurostat and the World Bank data are used for the selected development indicators $[6-8,16]$. Figure 1 shows the trends for the "Percentage of Individuals" that booked online in the EU28 and seven SEECs for the period 2009-2013. The EU28 yearly average increase was $1.8 \%$ for the corresponding period.

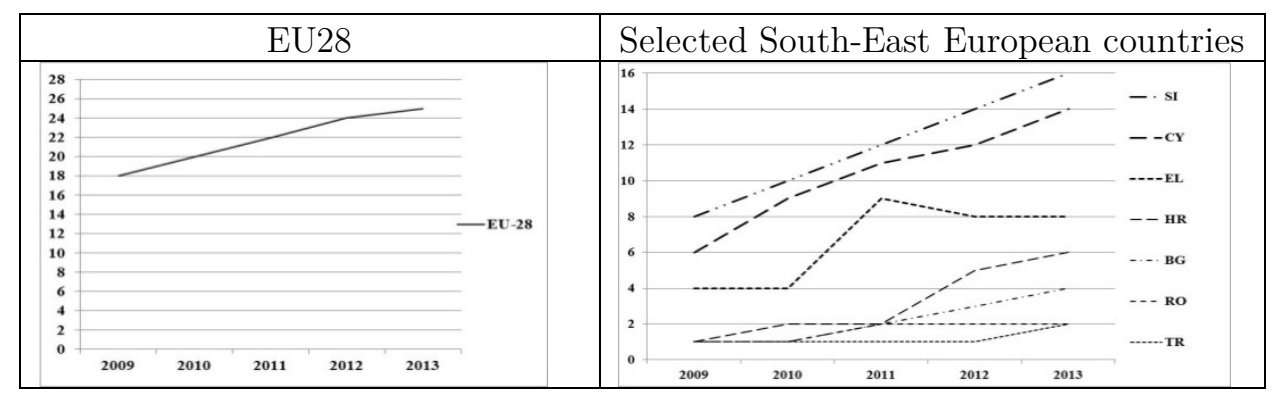

Figure 1: The Percentage of Individuals who booked travel and holiday accommodation on the Internet during the last 12 months ( $\left.Y_{\text {IntBook }}\right)$ from the EU28 and selected SEECs, 2009-2013. 
European countries: a multivariate analysis approach

Figure 2 shows the trend for the Internet Penetration Rate for the EU27 over the last decade with a yearly average increase of $3.3 \%$.

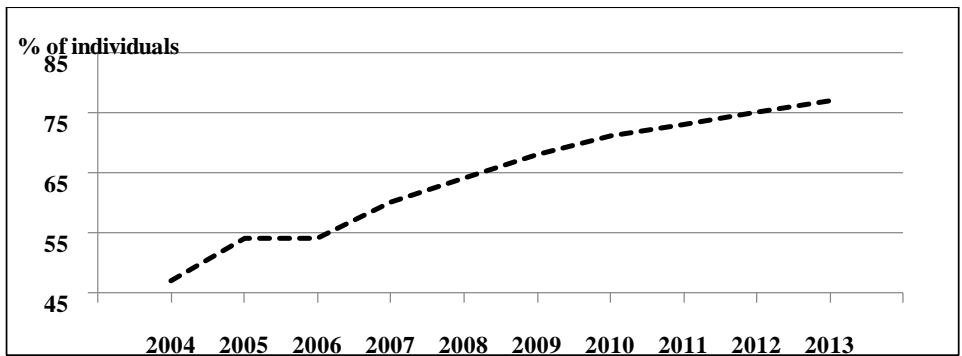

Figure 2: The Percentage of Individuals who used the Internet in the last 12 months (Internet Penetration Rate) in EU27, 2004-2013

For the purpose of recognizing the ranges, as well as identifying countries at the top and at the bottom (with especially denoted SEECs), the highest and the lowest values for each variable in the dataset are given in Table 1.

\begin{tabular}{|c|c|c|c|c|c|c|}
\hline \multirow[b]{3}{*}{$\begin{array}{l}\text { Type of impact on the } \\
\text { main variable under } \\
\text { study }\end{array}$} & \multirow{2}{*}{\multicolumn{2}{|c|}{ Variable }} & \multicolumn{2}{|c|}{ Highest } & \multicolumn{2}{|c|}{ Lowest } \\
\hline & & & $\begin{array}{c}\text { Country } \\
\text { code }\end{array}$ & Value & $\begin{array}{c}\text { Country } \\
\text { code }\end{array}$ & Value \\
\hline & & $\begin{array}{l}\text { The main variable } \\
\text { under study: } \\
\text { YIntBook, the percentage of } \\
\text { individuals }\end{array}$ & $\begin{array}{c}\text { DK } \\
\text { SE } \\
\text { FI, LU } \\
\text { NL, UK }\end{array}$ & $\begin{array}{l}56 \\
54 \\
45 \\
44 \\
\end{array}$ & $\begin{array}{l}\text { RS, MK } \\
\text { TR, RO } \\
\text { BG }\end{array}$ & $\begin{array}{l}1 \\
2 \\
4\end{array}$ \\
\hline Economic impact & $\frac{\sqrt{0}}{0.0}$ & $\begin{array}{c}\mathrm{X}_{\mathrm{GDPp}}, \\
\text { in PPS, Index, EU-28=100 }\end{array}$ & $\begin{array}{c}\text { LU } \\
\text { AT } \\
\text { NL, SE } \\
\text { IE }\end{array}$ & $\begin{array}{l}264 \\
129 \\
127 \\
126\end{array}$ & $\begin{array}{l}\text { MK } \\
\text { RS } \\
\text { BG } \\
\text { RO } \\
\text { TR }\end{array}$ & $\begin{array}{l}35 \\
36 \\
47 \\
54 \\
55\end{array}$ \\
\hline $\begin{array}{c}\text { Economic impact on } \\
\text { education }\end{array}$ & 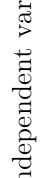 & $\begin{array}{c}\text { X ExpEdu, } \\
\% \text { of GDP } \\
\text { estimate based on } 2010\end{array}$ & $\begin{array}{c}\text { DK } \\
\text { CY } \\
\text { SE } \\
\text { MT } \\
\text { FI } \\
\end{array}$ & $\begin{array}{l}8.7 \\
7.3 \\
7.0 \\
6.9 \\
6.8 \\
\end{array}$ & $\begin{array}{c}\text { TR } \\
\text { MK } \\
\text { LU } \\
\text { EL, BG }\end{array}$ & $\begin{array}{l}2.9 \\
3.5 \\
3.7 \\
4.1\end{array}$ \\
\hline ICT use impact & 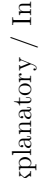 & $\begin{array}{c}\mathrm{X}_{\text {IntUse, }} \\
\text { Internet penetration rate }\end{array}$ & $\begin{array}{c}\text { SE } \\
\text { DK } \\
\text { NL } \\
\text { LU } \\
\text { FI }\end{array}$ & $\begin{array}{l}94.8 \\
94.7 \\
94.0 \\
93.8 \\
91.5\end{array}$ & $\begin{array}{l}\text { TR } \\
\text { RO } \\
\text { RS } \\
\text { BG } \\
\text { IT }\end{array}$ & $\begin{array}{l}46.3 \\
49.8 \\
51.5 \\
53.1 \\
58.5\end{array}$ \\
\hline ICT skills impact & 坣 & $\begin{array}{c}\mathrm{X}_{\text {Intskill, }} \\
\% \text { of the total number of } \\
\text { individuals aged } 16 \text { to } 74\end{array}$ & $\begin{array}{l}\mathrm{DE} \\
\mathrm{NL} \\
\mathrm{AT}, \mathrm{IE} \\
\mathrm{FR}\end{array}$ & $\begin{array}{l}46 \\
36 \\
35 \\
34\end{array}$ & $\begin{array}{c}\text { LT } \\
\text { IT } \\
\text { RS, HU } \\
\text { PT, EL }\end{array}$ & $\begin{array}{l}12 \\
19 \\
20 \\
21\end{array}$ \\
\hline
\end{tabular}

Table 1: Extreme values of the observed variables for 2013 by countries 
In 2013, the highest percentage of individuals who made bookings online in the last 12 months was in Denmark (56\%) and Sweden (54\%). The lowest percentages were in Croatia (6\%), Bulgaria (4\%) and Romania (2\%).

For the purpose of exploring possible outliers, standardized data for all five analyzed variables from 31 countries for 2013 are displayed in the multiple BoxPlot in Figure 3. Figure 3 shows a serious outlier for $\mathrm{X}_{\mathrm{GDPp}}$ for Luxembourg with the standardized value $\mathrm{z}=4.05$. Although, the variable $\mathrm{X}_{\text {IntSkill }}$ for Germany has $\mathrm{z}=2.9$, which might be a mild outlier, these data remain in the further analysis.

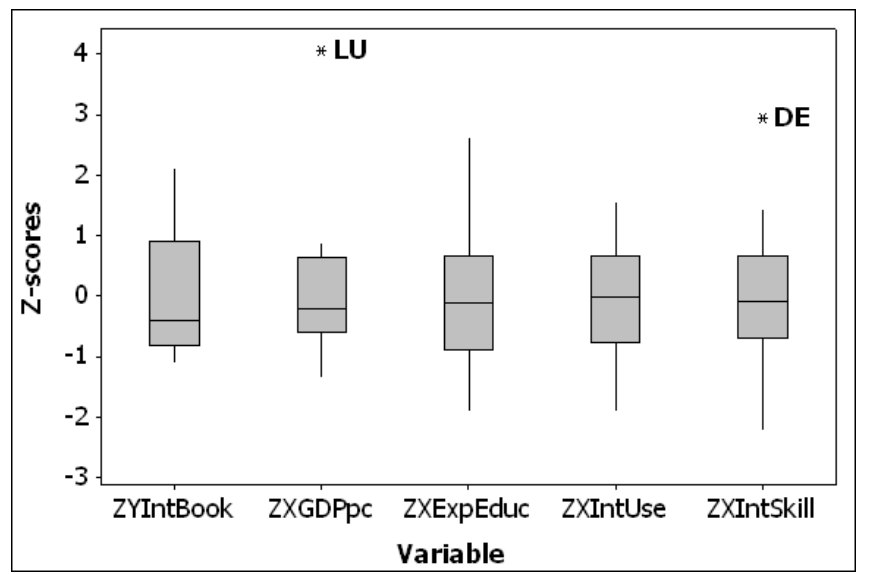

Figure 3: Boxplots of standardized variables, $n=31$ data for 2013

After omitting outlying data for Luxembourg, further exploratory analysis was made for 30 countries. The basic descriptive results are given in Table 2 .

\begin{tabular}{|l|c|c|c|c|c|}
\hline \multirow{2}{*}{ Statistics } & \multicolumn{5}{c|}{ Variable } \\
\cline { 2 - 6 } & $\mathrm{Y}_{\text {IntBook }}$ & $\mathrm{X}_{\mathrm{GDPpc}}$ & $\mathrm{X}_{\text {ExpEduc }}$ & $\mathrm{X}_{\text {IntUse }}$ & $\mathrm{X}_{\text {IntSkill }}$ \\
\hline $\mathrm{N}$ & 30 & 30 & 30 & 30 & 30 \\
\hline Mean & 18.97 & 86.47 & 5.41 & 72.35 & 26.43 \\
\hline Median & 12.00 & 81.50 & 5.30 & 72.66 & 26.00 \\
\hline Std. Deviation & 16.67 & 28.56 & 1.26 & 13.70 & 6.62 \\
\hline Coefficient of Variation & $87.88 \%$ & $33.03 \%$ & $23.33 \%$ & $18.93 \%$ & $25.05 \%$ \\
\hline Skewness & 0.94 & 0.02 & 0.41 & -0.06 & 0.72 \\
\hline Kurtosis & -0.36 & -1.03 & 0.41 & -0.75 & 1.61 \\
\hline Range & 55.00 & 94.00 & 5.88 & 48.53 & 34.00 \\
\hline Minimum & 1.00 & 35.00 & 2.86 & 46.25 & 12.00 \\
\hline Maximum & 56.00 & 129.00 & 8.74 & 94.78 & 46.00 \\
\hline
\end{tabular}

Table 2: Exploratory analysis of the observed variables, without data for Luxembourg $(n=30)$ for the year 2013 
European countries: a multivariate analysis approach

Data dispersion for the 30 countries is moderate across all variables, with the exception of $\mathrm{Y}_{\text {IntBook }}$ for which the coefficient of variation is very high, $\mathrm{CV}=88 \%$. Data distributions are almost symmetric for variables $\mathrm{X}_{\mathrm{GDPpc}}$ and $\mathrm{X}_{\text {IntUse }}$, while the distributions of other variables are positively skewed, indicating one or more exceptionally high values.

\section{Correlations and regression modelling}

The analyzed scatter diagrams and estimated Pearson correlation coefficients show a positive linear correlation between the pairs of investigated variables. At a $1 \%$ significance level, all the correlations are statistically significant except the one between the variables $\mathrm{X}_{\text {ExpEduc }}$ and $\mathrm{X}_{\text {IntSkill }}$, which is somewhat surprising. In regression modelling, $\mathrm{Y}_{\text {IntBook }}$ is used as a dependent variable, whereas $\mathrm{X}_{\mathrm{GDPpc}}$, $\mathrm{X}_{\text {ExpEduc }}, \mathrm{X}_{\text {IntUse }}$ and $\mathrm{X}_{\text {IntSkill }}$ are the independent variables. Based on pre-set criteria, only three regression models, among possible 15 linear regression models, had an $\mathrm{R}^{2}$ higher than 0.80 and all the independent variables statistically significant at $5 \%$ were analyzed in detail. Finally, three interpretable multiple linear regression models were estimated using ordinary least squares (OLS).

The estimated Model 1, which includes two independent variables, $\mathrm{X}_{\mathrm{GDPpc}}$ and $\mathrm{X}_{\text {IntUse, }}$, is given in (1) as follows:

$$
\begin{aligned}
& \hat{Y}_{\text {IntBook }}=-48.8+0.3 \cdot X_{G D P p C}+0.6 \cdot X_{\text {IntUse }} \quad n=30, \quad R^{2}=0.85, \quad \bar{R}^{2}=0.84 \\
& \hat{\sigma}=6.8, \quad \hat{V}=35.7 \%, \quad F=74.2
\end{aligned}
$$

Based on the overall F-test, the entire model is statistically significant at the $1 \%$ significance level (p-value $\approx 0.000)$. The regressor $\mathrm{X}_{\mathrm{GDPpc}}$, with $t$ ratio $=3.60$ (p-value $=0.001)$, and the regressor $\mathrm{X}_{\text {IntUse }}$, with $t$-ratio $=3.92(\mathrm{p}$ value $=0.001$ ), are both statistically significant at the $1 \%$ significance level. The diagnostic results from the linear regression model confirmed that all model assumptions were met in the regression model given above. The adjusted coefficient of determination indicated that two regressors, $\mathrm{X}_{\mathrm{GDPpc}}$ and $\mathrm{X}_{\mathrm{IntUse}}$, account for $84 \%$ of the total variation in $\mathrm{Y}_{\text {IntBook }}$. The regression coefficient of variation, which equals $\hat{V}=35.7 \%$, indicates that the regression model is representative. According to (1), a one index point increase in $\mathrm{X}_{\mathrm{GDPpc}}$, with $\mathrm{X}_{\text {IntUse }}$ remaining constant, leads to a 0.3 percentage point increase in $\mathrm{Y}_{\text {IntBook. }}$. If $\mathrm{X}_{\text {IntUse }}$ increases by one percentage point, while holding the variable $\mathrm{X}_{\mathrm{GDPp}}$ constant, the regression value of $\mathrm{Y}_{\text {IntBook }}$ increases by 0.6 percentage points. 
Model 2 has three independent variables with the corresponding estimates and the main indicators given in (2):

$$
\begin{aligned}
& \hat{Y}_{\text {IntBook }}=-67.5+4.3 \cdot X_{\text {ExpEduc }}+0.7 \cdot X_{\text {IntUse }}+0.5 \cdot X_{\text {Inskill }} \quad n=30, \quad R^{2}=0.83, \quad \bar{R}^{2}=0.82
\end{aligned}
$$

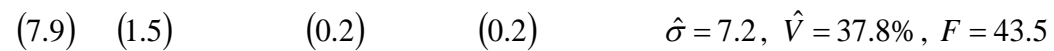

All the three regressors $\mathrm{X}_{\text {ExpEduc }}(t$-ratio $=2.78, \mathrm{p}$-value $=0.010), \mathrm{X}_{\text {IntUse }}(t$ ratio $=4.39, \quad \mathrm{p}$-value $\approx 0.000)$ and $\mathrm{X}_{\text {Intskill }}(t$-ratio $=2.18, \quad \mathrm{p}$-value $=0.039)$ are statistically significant at the $5 \%$ significance level. The overall F-test pointed out that the entire model is statistically significant at the significance level of $1 \%$ (p-value $\approx 0.000$ ). According to the performed regression diagnostics, all regression model assumptions were met. The adjusted coefficient of determination indicates that the three regressors, $\mathrm{X}_{\text {ExpEduc }}, \mathrm{X}_{\text {IntUse }}$ and $\mathrm{X}_{\text {IntSkill }}$, account for $82 \%$ of the total variation in $\mathrm{Y}_{\text {IntBook }}$. The regression coefficient of variation $(\hat{V}=37.8 \%)$ indicates that the regression model might be considered as acceptably representative. Regression Model 2 indicates that a one percentage point increase in $\mathrm{X}_{\text {ExpEduc }}$, while holding other variables $\left(\mathrm{X}_{\text {IntUse }}\right.$ and $\mathrm{X}_{\text {IntSkill }}$ ) constant, leads to a 4.3 percentage point increase in the $\mathrm{Y}_{\text {IntBook. }}$. According to (2), a one percentage point increase in $\mathrm{X}_{\text {IntUse }}$, while holding other variables $\left(\mathrm{X}_{\text {ExpEduc }}\right.$ and $\left.\mathrm{X}_{\text {IntSkill }}\right)$ constant, leads to the increase in the regression value of $\mathrm{Y}_{\text {IntBook }}$ by 0.7 percentage points. If $\mathrm{X}_{\text {IntSkill }}$ is increased by one percentage point, while holding other variables $\left(\mathrm{X}_{\text {ExpEduc }}\right.$ and $\left.\mathrm{X}_{\text {IntUse }}\right)$ constant, the regression value of $\mathrm{Y}_{\text {IntBook }}$ increases by 0.5 percentage points.

The estimated Model 3, with two independent variables, $\mathrm{X}_{\text {ExpEduc }}$ and $\mathrm{X}_{\text {IntUse }}$, and its main indicators are given in (3), as follows:

$$
\begin{array}{cccc}
\hat{Y}_{\text {IntBook }}=-61.0+3.2 \cdot X_{\text {ExpEduc }}+0.9 \cdot X_{\text {IntUse }} & n=30, & R^{2}=0.80, & \bar{R}^{2}=0.79 \\
(7.7)(1.6) & (0.1) & \hat{\sigma}=7.7, \quad \hat{V}=40.37 \%, \quad F=55.2
\end{array}
$$

The overall F-test shows that the entire model is statistically significant at the $1 \%$ significance level ( $\mathrm{p}$-value $\approx 0.000)$. The regressors $\mathrm{X}_{\text {ExpEduc }}(t$-ratio $=2.08$, $\mathrm{p}$-value $=0.047)$ and $\mathrm{X}_{\text {Intuse }}(t$-ratio $=6.01, \mathrm{p}$-value $\approx 0.000)$ are both statistically significant at the significance level of $5 \%$. Diagnostic results from the linear regression model have confirmed that none of the model assumptions was violated in regression Model 3. The adjusted coefficient of determination is slightly below $0.80\left(\bar{R}^{2}=0.79\right)$, but still has a high value. The regression coefficient of variation ( $\hat{V}=40.37 \%$ ) indicates that the regression model is still representative. According to (3), a one percentage point increase in $\mathrm{X}_{\text {ExpEduc }}$, while holding $\mathrm{X}_{\text {IntUse }}$ constant, would lead to 3.2 percentage points increase in $\mathrm{Y}_{\text {IntBook}}$. Increasing $\mathrm{X}_{\text {IntUse }}$ by one percentage point, while holding the variable $\mathrm{X}_{\text {ExpEduc }}$ constant, results in the regression value of $\mathrm{Y}_{\text {IntBook }}$ increasing by 0.9 percentage points. 
European countries: a multivariate analysis approach

\section{Hierarchical and non-hierarchical clustering of countries}

According to Hair et al. [11], the hierarchical clustering of 30 countries using standardised values for all five variables for 2013, subject to the Ward linkage and the Euclidian distances, resulted in the three clusters given in Table 3 and which Figure 4 shows in the form of tree-diagram. The asterisks in Table 3 denote the SEE countries.

\begin{tabular}{|c|c|l|}
\hline $\begin{array}{c}\text { Cluster } \\
\text { no. }\end{array}$ & $\begin{array}{c}\text { No. of } \\
\text { countries }\end{array}$ & \multicolumn{1}{c|}{ Countries } \\
\hline Cluster 1 & 15 & $\begin{array}{l}\text { Lithuania, Portugal, Poland, Italy, Greece*, Malta, Cyprus*, Latvia, } \\
\text { Hungary, Estonia, Spain, Slovenia*, Slovakia, the Czech Republic, } \\
\text { Croatia* }\end{array}$ \\
\hline Cluster 2 & 5 & Turkey*, Romania*, the FYR of Macedonia*, Serbia*, Bulgaria* \\
\hline Cluster 3 & 10 & $\begin{array}{l}\text { the Netherlands, Sweden, the United Kingdom, Finland, Denmark, } \\
\text { Germany, Belgium, France, Ireland, Austria }\end{array}$ \\
\hline
\end{tabular}

Table 3: The hierarchical clustering of European countries with the three-cluster solution (the Ward linkage, the Euclidean distances, 30 countries, five variables, standardized data for 2013)

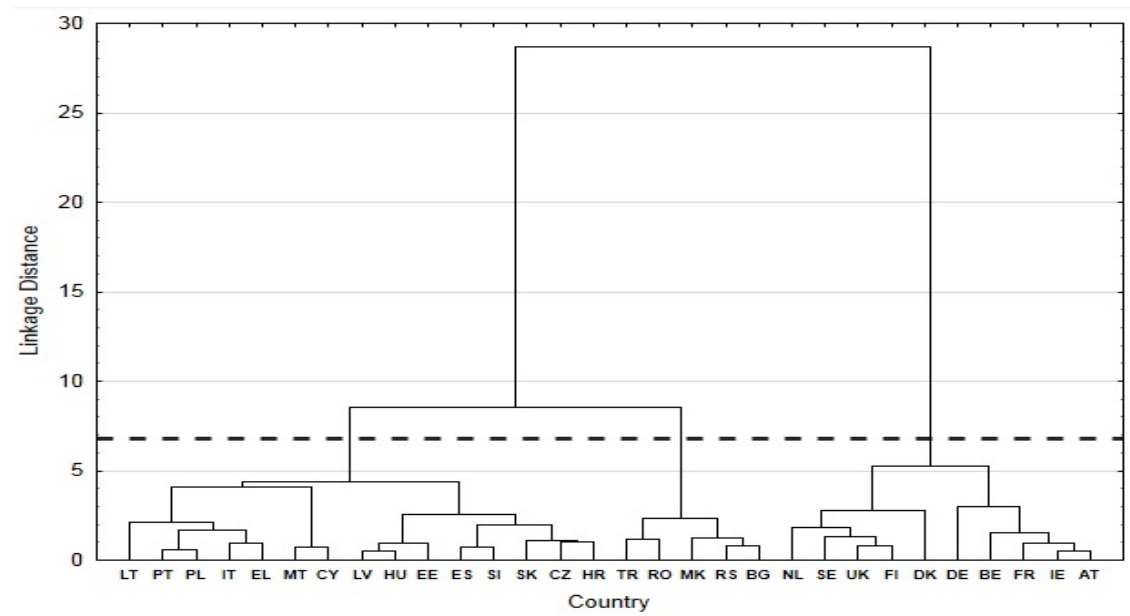

Figure 4: The tree-diagram (the Ward linkage, the Euclidean distances, 30 countries, five variables standardized data for 2013)

In the three-cluster solution of the presented hierarchical clustering, the SSECs are grouped into two clusters: one with five countries (Turkey*, Romania*, the FYR of Macedonia*, Serbia*, Bulgaria*), and the remaining with four SEECs (Greece*, Cyprus*, Slovenia*, Croatia*) are grouped into 11 others, all EU members and candidate countries. The multiple profile diagrams charting five variables for selected country groups of SEECs are given in Figure 5 and Figure 6 . 
The three-cluster solution obtained by non-hierarchical k-means clustering resulted in the country clusters as given in Table 4.

"The most developed" EU countries with respect to the five analyzed variables are clustered in Cluster 1. The cluster contains the following 10 "old" EU countries: Austria, Belgium, Denmark, Finland, France, Germany, Ireland, the Netherlands, Sweden, and the United Kingdom. The conclusion is that Denmark is the most developed among these developed countries according to the observed variables. In fact, Denmark has the highest values for the variables $\mathrm{Y}_{\text {IntBook }}$ and $\mathrm{X}_{\text {ExpEduc, }}$, as well having the best ranking according to the variables $\mathrm{X}_{\mathrm{GDPpc}}$ and $\mathrm{X}_{\text {IntUse. }}$ The final confirmation that Denmark is the most developed comes from the fact that it has the lowest rate of people possessing low Internet skills $\left(\mathrm{X}_{\text {IntSkill }}\right)$ in the cluster.

Cluster 2 includes 13 "less developed" EU countries with respect to the five analyzed variables: the Czech Republic, Estonia, Hungary, Italy, Lithuania, Latvia, Malta, Poland, Portugal, Slovakia, Spain, and the last two, Slovenia* and Cyprus*, which are part of the SEE. There is no similar dominant country in Cluster 2 as there is in Cluster 1. The best country in Cluster 2 is Spain according to variable $\mathrm{Y}_{\text {IntBook, }}$ Italy according to variable $\mathrm{X}_{\mathrm{GDPp}}$, Cyprus according to variable $\mathrm{X}_{\text {ExpEduc }}$, Estonia according to variable $\mathrm{X}_{\text {IntUse, and }}$ Lithuania according to variable $\mathrm{X}_{\text {IntSkill }}$.

Cluster 3 contains 7 SEE countries, of which $4 \mathrm{EU}$ are member states: Bulgaria*, Croatia*, Greece*, Romania*, and 3 are official EU candidate countries: the FYR of Macedonia*, Serbia* and Turkey*. In this cluster, Greece has the best values for variables $Y_{\text {IntBook }}$ and $X_{G D P p c}$. Serbia has the best values for variables $\mathrm{X}_{\text {ExpEduc }}$ and $\mathrm{X}_{\text {IntSkill }}$ in Cluster 3 . Croatia is the best country in Cluster 3 according to the variable $\mathrm{X}_{\text {IntUse }}$.

\begin{tabular}{|c|c|l|}
\hline $\begin{array}{c}\text { Cluster } \\
\text { no. }\end{array}$ & $\begin{array}{c}\text { No. of } \\
\text { countries }\end{array}$ & \multicolumn{1}{|c|}{ Countries } \\
\hline Cluster 1 & 10 & $\begin{array}{l}\text { Austria, Belgium, Denmark, Finland, France, Germany, Ireland, the } \\
\text { Netherlands, Sweden, the United Kingdom }\end{array}$ \\
\hline Cluster 2 & 13 & $\begin{array}{l}\text { Cyprus*, the Czech Republic, Estonia, Hungary, Italy, Lithuania, } \\
\text { Latvia, Malta, Poland, Portugal, Slovakia, Slovenia*, Spain }\end{array}$ \\
\hline Cluster 3 & 7 & $\begin{array}{l}\text { Bulgaria*, Croatia*, the FYR of Macedonia*, Greece*, Romania*, } \\
\text { Serbia*, Turkey* }\end{array}$ \\
\hline
\end{tabular}

Table 4: Non-hierarchical clustering of European countries with the three-cluster solution (five variables standardized data for 2013)

When focusing on the SSE countries, different clustering methods do result in some differences in three-cluster solutions. In spite of the differences in country classifications when applying different clustering methods, the conclusion is that the same five SEE countries (Bulgaria*, Romania*, the FYR of Macedonia*, Serbia* and Turkey*) are classified together in the nonhierarchical cluster analysis with three clusters. In the hierarchical clustering, 
Croatia* and Greece* are also included in the SEE countries cluster. Based on the same procedure, Slovenia* and Cyprus* belong to the more developed part of the SEE. Regarding the variables under study Slovenia* and Cyprus* join the cluster of "developing" EU countries, such as the Czech Republic, Estonia, Hungary, Italy, Lithuania, Latvia, Malta, Poland, Portugal, Slovakia and Spain. At the same time, the most developed EU countries all remained in a separate cluster.

The multiple profile diagram for the five SEE countries in their own cluster is shown in Figure 5. The multiple profile diagram for the four SEE countries that join a cluster with several more developed EU countries in all clustering procedures is shown in Figure 6.

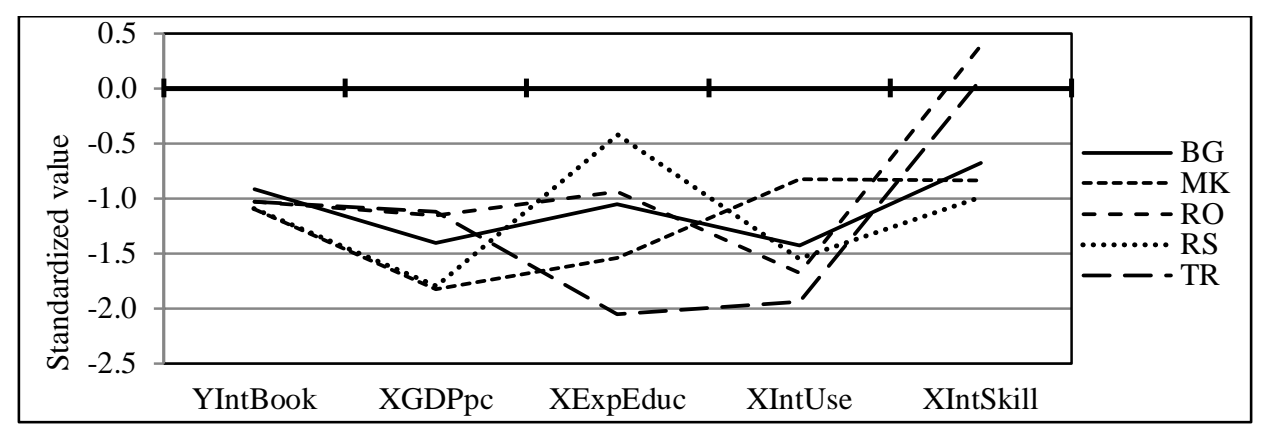

Figure 5: The multiple profile diagram for the five SEE countries in their own cluster resulted from both hierarchical and non-hierarchical clustering methods (standardized data for 2013)

The profile diagram for the five less developed SEE countries in Figure 5 shows that Bulgaria, the FYR of Macedonia and Serbia are all below the average for the 30 European countries in terms of all the variables, whereas Romania and Turkey are approaching this average for variable $\mathrm{X}_{\text {IntSkill }}$.

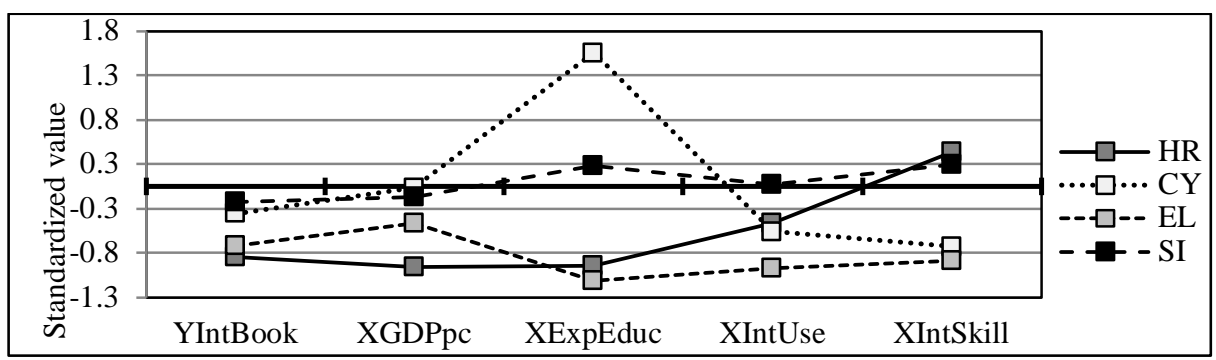

Figure 6: Multiple profile diagram for the four SEE countries that joined the more developed EU country clusters based on the clustering method (standardized data for 2013)

When looking at the variable $\mathrm{X}_{\text {expEduc }}$ at Figure 6, which is constructed for the four SEE countries that joined more developed EU countries' clusters, it 
can be seen that Cyprus is 1.5 and Slovenia is 0.25 standard deviations above the average of 30 analyzed countries. Focusing on the variable $\mathrm{X}_{\text {IntSkill, }}$ Croatia is 0.4 and Slovenia is 0.25 standard deviations above the average. Greece is below the average in all the variables.

\section{Conclusion}

High positive correlations between the pairs of the five variables for 30 European countries in 2013 were found when studying the impacts of ICT and economic development indicators on the Percentage of Individuals who booked travel and holiday accommodation online. A one index point increase in gross domestic product per capita in Purchasing Power Standards (EU28=100), while holding the constant Percentage of Individuals using the Internet, leads to a 0.3 percentage point increase in the Percentage of Individuals who booked travel and holiday accommodation online the last 12 months. If the Percentage of individuals using the Internet increased by one percentage point, while holding the variable gross domestic product per capita in Purchasing Power Standards (EU28=100) constant, the regression value of Percentage of Individuals who booked travel and holiday accommodation online during the last 12 months increases by 0.6 percentage points.

In spite of the differences in country classifications when applying different clustering methods, the conclusion is that the same five South Eastern European (SEE) countries (Bulgaria*, Romania*, the FYR of Macedonia*, Serbia* and Turkey*) are classified together in the non-hierarchical cluster analysis with three clusters as in the hierarchical clustering. In the hierarchal clustering Croatia* and Greece* joining them too. The same procedure in terms of the analyzed variables leads to Slovenia* and Cyprus* becoming part of the more developed SEE countries, joining the cluster of "developing" European Union (EU) countries. Coincidently, the most developed EU countries are a part of a separate cluster. Meaning that 10 of the "old" European Union member states comprising Austria, Belgium, Denmark, Finland, France, Germany, Ireland, the Netherlands, Sweden, and the United Kingdom are clustered together.

The country profile diagrams show that Slovenia and Cyprus are above the average share of Gross Domestic Product given for education, which also positively influences the Internet booking level. Similarly, Romania and Turkey come close, while Croatia and Slovenia slightly exceed the average level of Internet skills. Bulgaria, Greece, the FYR of Macedonia and Serbia, are all below the average for the observed variables. Furthermore, Croatia did not enter the group of other Western Balkan countries.

Given that the modern consumer is becoming increasingly influenced by the Internet, the presented analysis results are useful for tourism operators and stakeholders in the tourism sector at the macroeconomic level, especially for the 
European countries: a multivariate analysis approach

considered SEE countries. Companies offering tourism services should reconsider the quality of their websites and provide consumers with user-friendly online booking features. In general, broadband and Internet penetration, and Internet literacy and skills should also be improved.

Since some European and SEE countries were not included in the analysis due to lack of data for the analyzed variables, this research is limited. The authors are encouraged by the fact that official data availability for European countries is improving each year, and they hope to include all the countries into their analysis in the near future. Moreover, it would be challenging to include the most developed European countries that are not EU member states, such an Iceland and Norway, simply to compare the performance of the main variable under study. Additionally, introducing more ICT and socio-economic development indicators into the research would be useful. In order to construct a complete model of online booking performance a deeper insight into the activities of enterprises offering these services should also be made.

\section{Acknowledgement}

This work has been fully supported by the Croatian Science Foundation under the project titled STRENGTHS (Project no. 9402, Period: 2014-2018).

\section{References}

[1] Alvarez, M., and Asugman, G. (2006). Explorers versus planners: A study of Turkish tourists. Annals of Tourism Research, 33, 319-338.

[2] Baggio, R. (2003). Websites analysis of European tourism organizations. International Journal of Tourism and Hospitality Research, 14(2), 93-106. doi: 10.1080/13032917.2003.9687019.

[3] Bonn, M. A, Furr, H. L., and Susskind, A.M. (1998). Using the Internet as a pleasure travel planning tool: An examination of the socio-demographic and behavioural characteristics among Internet users and nonusers. Journal of Hospitality and Tourism Research, 22(3), 303-317. doi: $10.1177 / 109634809802200307$.

[4] Dixit, M., Belwal, R., and Singh, G. (2006). Online tourism and travel (analyzing trends from marketing perspective). Skyline Business School Journal, 3, 89-99.

[5] European Commission. (2013). Flash Eurobarometer 370. http://ec.europa.eu/public_opinion/flash/f1_370_en.pdf [Accessed on 06 July 2014].

[6] Eurostat. (2014a). GDP per capita in PPS. http://epp.eurostat.ec.europa.eu/tgm/table.do?tab=table\&init=1\&plugin=1\&la nguage $=$ en\&pcode=tec00114 [Accessed on 04 July 2014].

[7] Eurostat. (2014b). Individuals' level of Internet skills. 
http://epp.eurostat.ec .europa.eu/tgm/table. do?tab=table\&init=1\&plugin=1\&la nguage $=$ en\&pcode $=$ tsdsc470 [Accessed on 04 July 2014].

[8] Eurostat. (2014c). Percentage of individuals using the Internet (Internet penetration rate), $\%$ of population.

http://appsso.eurostat.ec.europa.eu/nui/show.do?dataset=isoc_ci_ifp_iu\&lan g=en [Accessed on 02 September 2014].

[9] Govers, R., and Go, F. M. (2003). Deconstructing destination image in the information age. Information Technology \& Tourism, 6, 13-29. doi: $10.3727 / 109830503108751199$.

[10] Grønflaten, Ø. (2009). Predicting travelers' choice of information sources and information channels. Journal of Travel Research, 48(2), 230-244. doi:10.1177/0047287509332333.

[11] Hair, F. J., Black, W. C., Babin, B. J., and Anderson E. R. (2010). Multivariate Data Analysis. 7th ed. Boston: Prentice Hall.

[12] Hanson, W. (2000). Principles of Internet Marketing. Ohio: South-Western College Pub.

[13] Moussis, N. (2014). Balkan countries and the EU. http://europedia.moussis.eu/books/Book_2/7/25/03/index.tkl?all=1\&pos=357 [Accessed on 02 September 2014].

[14] Scharlr, A., Wöber, K., and Bauer, C. (2003). An integrated approach to measure web site effectiveness in the European hotel industry. Journal of IT \& Tourism, 6(4), 257-271. doi:10.3727/1098305032781157.

[15] Škuflić, L., and Štoković, I. (2011). Demand function for croatian tourist product: A panel data approach. Modern Economy, 2, 49-53. doi:10.4236/me.2011.21008.

[16] The World Bank. (2014). Public spending on education, total (\% of GDP). http://data.worldbank.org/indicator/se.xpd.totl.gd.zs [Accessed on 04 July 2014].

[17] Vich-i-Martorell, G. À. (2004). The internet and tourism principals in the Balearic Islands. Tourism and Hospitality Research, 5, 25-44.

doi:10.1057/palgrave.thr.6040003. 